\title{
Meningkatkan Pengendalian Penyimpangan Sosial Melalui Pembelajaran Berdasarkan Masalah Siswa SDN 30 Rumaju
}

\author{
Nurhasni Rabia Paembonan \\ SD Negeri 30 Rumaju \\ e-mail: ibu_nurhasi@yahoo.com
}

\begin{abstract}
Abstrak:. Penelitian Tindakan Kelas ini bertujuan untuk membantu meningkatkan kompetensi siswa kelas VI di SD Negeri 30 Rumaju Kecamatan Bajo Kabupaten Luwu, dalam hal peningkatan pengendalian penyimpanan Sosial. Pendekatan yang digunakan adalah pendekatan kualitatif dengan jenis penelitian tindakan kelas yang dilaksanakan dilakukan dalam tiga tahapan, yaitu persiapan, pelaksanaan dan evaluasi dan refleksi, dan dilakukan minimal dalam dua siklus. Pada tahap persiapan dibuat skenario kegiatan, jadwal waktu, tempat serta sarana pendukung lainnya seperti lembar observasi, serta angket. Hasil penelitian menunjukkan bahwa 1) Model Pembelajaran berdasarkan masalah (problem based introduction) dalam pelajaran IPS dapat meningkatkan baik prestasi akademik atau kognitif maupun perubahan sikap (afektif). Peningkatan kemampuan kognitif dapat dilihat pada peningkatan hasil belajar yang signifikan antara siklus I dengan Siklus II yaitu dari nilai rata-rata 64,07 menjadi 73,10. 2) Secara kualitatif terjadi perubahan sikap siswa dengan melakukan kegiatan-kegiatan positif berupa peningkatan perhatian, motivasi, dan minat siswa terhadap pelajaran IPS terutama pemahaman pengendalian penyimpangan sosial. Sikap demokratis serta kerja sama antara siswa menjadi lebih baik dengan semakin minimnya sekat-sekat kelompok seperti yang ada sebelum pelaksanaan model pembelajaran ini.
\end{abstract}

Kata kunci : penyimpangan sosial; pembelajaran; berdasarkan masalah

\begin{abstract}
This classroom action research aims to help improve the competence of grade 6 students at SD Negeri 30 Rumaju, Luwu Regency, in the case of improving Social storage control. The approach used is a qualitative approach with classroom action research conducted in three stages, namely preparation, implementation and evaluation and reflection, and carried out in at least two cycles. In the preparation phase, scenarios of activities, timelines, places and other supporting facilities such as observation sheet, and questionnaire are prepared. The results showed that 1) Problem-based learning model in IPS lesson can improve both academic or cognitive achievement and attitude change (affective). Increased cognitive ability can be seen in the improvement of learning outcomes that are significant between cycle I with Cycle II that is from the average value of 64.07 to 73.10. 2) Qualitatively there is a change in the attitude of students by doing positive activities in the form of increasing attention, motivation, and interest of students to IPS lesson especially understanding of control of social deviation. Democratic attitudes and cooperation between students become better with the lack of group barriers as they existed before the implementation of this learning model.
\end{abstract}

Keywords: social deviation; learning; based on the problem; 


\section{PENDAHULUAN}

Dalam kehidupan sehari-hari tidak semua orang bertindak berdasarkan norma-norma dan nilai sosial yang berlaku dalam masyarakat. Untuk mencegah atau mengatasi terjadinya penyimpangan sosial perlu adanya pengendalian sosial. Didalam pengendalian sosial terdapat berbagai macam atau jenis pengendalian sosial. Di dalam melaksanakan pengendalian sosial tidak terlepas dari lembaga-lembaga sosial yang menanganinya.

Guru harus mencari alternatif berinteraksi agar materi pengendalian penyimpangan sosial dapat diterapkan dengan mudah dan juga dipahami siswa. Salah satu hal yang dilakukan adalah dengan model pembelajaran berdasarkan masalah (Problem Based Introduction).

Menurut Agus (2008) pembelajaran berdasarkan masalah adalah model pembelajaran yang menyajikan kepada siswa situasi masalah yang autentik dan bermakna yang dapat memberikan kemudahan kepada mereka untuk melakukan penyelidikan atau inkuiri. Peranan guru dalam pembelajaran ini adalah mengajukan masalah, memfasilitasi penyelidikan dan dialog siswa, serta mendukung aktivitas belajar siswa. Model ini diorganisasikan di sekitar situasi kehidupan nyata yang menghindari jawaban sederhana dan mengundang persaingan pemecahan masalah, penyelidikan autentik, kerja sama, serta menghasilkan karya yang dapat diperagakan.

Di tingkat SD, pengajaran IPS diarahkan ke penanaman nilai-nilai dan norma-norma yang terdapat dalam tata kehidupan bermasyarakat. Anak didik selain diberikan pada latihan agar senantiasa dapat bergaul dan bekerja bersama dalam konteks keragaman, juga dibekali pengetahuan teoretis mengenai pengendalian penyimpangan sosial dengan model pembelajaran berdasarkan masalah. Mereka diajar menghubungkan antara pengetahuan teori dan pengalaman nyata dalam pergaulan seharihari. Selanjutnya mereka dilatih agar mampu menganalisis hakikat suatu tindakan yang berhubungan dengan kepentingan orang banyak.

Terdorong adanya permasalahan yang tak kunjung selesai, maka penulis terinspirasi melakukan sebuah penelitian dalam bentuk tindakan kelas sebagai langkah awal menuju pengendalian penyimpangan sosial dalam kehidupan siswa baik sebagai siswa maupun dalam kapasitasnya sebagai anggota masyarakat. Penelitian Tindakan Kelas ini berjudul "Meningkatkan Pengendalian Penyimpangan Sosial melalui Pembelajaran Berdasarkan Masalah Siswa Kelas VI SDN 30 Rumaju Kec. Bajo Kab. Luwu ".

\section{METODE PENELITIAN}

Penelitian tindakan kelas ini dilaksanakan di kelas VI SDN 30 Rumaju Kec. Bajo Kab. Luwu tahun pelajaran 2016/2017 dengan jumlah siswa sebanyak 30 orang yang terdiri atas 10 orang wanita dan 20 orang laki-laki. Secara garis besar dapat dikatakan bahwa kemampuan akademis siswa-siswi tersebut cukup merata baik dalam bidang kognitif, afektif, maupun psikomotorik.

Dalam bidang IPS, kemampuan siswa juga cenderung sama yang ditandai dengan skor perolehan pada pada tes awal maupun nilai-nilai yang tertera pada laporan hasil belajar. Dengan demikian, model pembelajaran yang diterapkan akan dapat direspon dengan baik oleh mayoritas siswa.

Untuk mendapatkan jawaban atas permasalahan yang telah dikemukakan di bagian depan, maka faktor-faktor berikut ini perlu diamati secara seksama: (1) Faktor siswa, yakni mengamati apakah model pembelajaran berdasarkan masalah dapat terlaksana dengan baik sehingga dapat meningkatkan kemampuan pengendalian penyimpangan sosial dalam tata kehidupan sehari-hari. (2) Faktor Bahan dan Sumber Pelajaran; yaitu mengamati apakah bahan ajar yang disampaikan dirancang dan dipersiapkan dengan baik. Relevan antara bahan ajar yang akan disajikan dengan teknik pembelajaran yang akan diterapkan sejalan dengan bahan ajar serta bersesuaian dengan konsep model pembelajaran berdasarkan masalah.

Prosedur pembelajaran berdasarkan masalah yang ditempuh melalui penelitian tindakan kelas ini dipilih menjadi 2 siklus yang terdiri atas empat kali pertemuan tatap muka untuk setiap siklus. Gambaran umum proses pembelajaran untuk setiap siklus adalah sebagai berikut:

1. Gambaran Umum Siklus 1

a. Rencana tindakan

1) Menelah Silabus/Suplemen dan Kurikulum Mata Pelajaran IPS untuk SD dan sederajat. 
2) Menyusun Rencana Pelaksanaan Pembelajaran berdasarkan kurikulum yang berlaku.

3) Membuat lembar observasi

4) Melaksanakan teks akhir

b. Pelaksanaan Tindakan

Siklus 1 dilakukan sebanyak empat kali pertemuan dengan materi sub-pokok bahasan yang diintegrasikan ke dalam pengajaran sub kompetensi kemampuan pengendalian penyimpangan sosial. Tindakan-tindakan yang dilakukan selama proses pembelajaran pada siklus 1 ini adalah sebagai berikut:

1) Menyampaikan Tujuan Pembelajaran

2) Menyajikan materi pembelajaran

3) Membagi siswa-siswi ke dalam kelompokkelompok kecil yang beranggo- takan 4 sampai 5 orang .

4) Mengajukan beberapa pertanyaan kepada siswa sebagai kegiatan awal.

5) Siswa diminta mengajukan pendapat atau ide tentang jawaban-jawaban yang diberikan pada langkah sebelumnya dan meyakinkan bahwa setiap anggota kelompok mengetahui jawabannya.

6) Memberikan latihan sebagai kegiatan penguatan (reinforcement).

c. Observasi

Kegiatan ini dilakukan untuk mengecek apakah siswa sudah benar-benar siap menerima pembelajaran melalui model pembelajaran berdasarkan masalah. Dalam konteks ini, penulis mencatat kejadian-kejadian sebelum, selama, dan setelah berlangsungnya proses pembelajaran untuk selanjutnya dianalisis.

d. Refleksi

Pada akhir siklus 1 diadakan kegiatan refleksi atau perenungan terhadap seluruh kegiatan yang telah dilakukan. Selain melalui lembaran observasi bahan refleksi juga diperoleh melalui wawancara atau tanya jawab dengan siswa. Kekurangan-kekurangan yang terdapat pada siklus 1 diperbaiki dan dilengkapi pada siklus berikutnya. Dalam konteks ini, peneliti mengevaluasi diri sendiri sehubungan dengan kegiatan pembelajaran yang dilakukan selama siklus 1 .

\section{Gambaran Umum Siklus 2}

Seperti halnya siklus 1 , siklus 2 juga dilaksanakan sebanyak empat kali pertemuan.

a. Rencana Tindakan

Kegiatan pada siklus 2 adalah kelanjutan dari siklus 1 dengan penambahan tindakan-tindakan yang dianggap perlu. Siswa tetap dikelompokkan ke dalam kelompok kecil sesuai kehendak model pembelajaran berdasarkan masalah. Kegiatan selanjutnya adalah memberikan soal-soal kepada semua kelompok untuk diselesaikan dan hasilnya dilaporkan didepan kelas.

Hal-hal yang perlu diperhatikan selama pelaksanaan siklus 2 ini adalah sebagai berikut:

1) Siswa diberikan pertanyaan-pertanyaan yang berhubungan dengan bahan ajar yang disampaikan pada siklus 1 .

2) Siswa atau kelompok yang kurang mampu menyelesaikan soal-soal yang diberikan bimbingan khusus seperlunya.

3) Guru harus mengatur tempo pembelajaran agar semua kegiatan yang direncanakan selesai tepat waktu.

4) Siswa atau kelompok yang mampu menyelesaikan soal-soal lebih cepat daripada kelompok lain diberi reward atau penghargaan atau pujian dan diberikan soal tambahan lain sebagai pengayaan.

5) Pada akhir siklus II diberikan soal-soal lain yang berhubungan dengan bahan ajar untuk mengetes tingkat pengetahuan siswa setelah melalui proses pembelajaran dengan menggunakan model pembelajarn berdasarkan masalah.

b. Pelaksanaan Tindakan

1) Guru tetap memberikan penjelasan sehubungan dengan bahan ajar yang dirancang dalam rencana pembelajaran.

2) Siswa dalam bentuk kelompok mengerjakan soal-soal

3) Soal-soal yang tidak dapat diselesaikan oleh kebanyakan kelompok dibahas secara bersama-sama dalam kelas.

4) Pada akhir siklus 2 diberikan ulangan dan selanjutnya diberikan angket tentang model pembelajaran berdasarkan masalah untuk ditanggapi oleh siswa.

\section{c. Observasi}

Seperti pada siklus 1, observasi dimaksudkan untuk mengecek perkembangan belajar yang dicapai oleh siswa. Setelah Penerapan model pembelajaran berdasarkan masalah, semua kejadian penting dicatat, misalnya perubahan tingkah laku dan hasil belajar yang dicapai berdasarkan pedoman observasi. 
d. Refleksi

Refleksi yang dilakukan meliputi seluruh kegiatan penelitian tindakan kelas pada siklus 1 dan 2. Data yang diperoleh berupa hasil wawancara, angket, observasi serta hasil ulangan tetap dianalisis.

Hal yang dijadikan parameter atau penilaian tentang keberhasilan penelitian tindakan kelas ini adalah terjadinya peningkatan kemampuan siswa kelas VI SDN 30 Rumaju Kec. Bajo Kab. Luwu tahun pelajaran 2016/2017 dalam pengendalian penyimpangan sosial dengan tepat hingga perolehan siswa mencapai ketepatan $65 \%$ atau lebih dari seluruh soal-soal yang diberikan.

\section{HASIL DAN PEMBAHASAN}

Hasil Tes Awal

Sebelum perlakuan berupa implementasi

model pembelajaran berdasarkan masalah terlebih dahulu dilakukan tes awal atau tes diagnostik dengan tujuan mengetahui kemampuan awal siswa tentang pengendalian penyimpangan sosial. Tes dilakukan dalam bentuk pilihan ganda dengan opsi empat buah per item soal. Jumlah soal seluruhnya adalah 10 item. Waktu yang disediakan untuk menyelesaikan soal-soal tersebut adalah 35 menit atau setara satu jam pelajaran. Namun beberapa orang siswa belum mampu menjawab soal-soal yang diberikan dengan ketepatan sampai $65 \%$. Selengkapnya hasil tes awal tersebut adalah sebagai berikut :

Tabel 1. Statistik Hasil Tes Awal

\begin{tabular}{ccc}
\hline NO & STATISTIK & NILAI \\
\hline 1. & Jumlah Siswa & 30 \\
\hline 2. & Nilai tertinggi & 65 \\
\hline 3 & Nilai terendah & 50 \\
\hline 4 & Rentang nilai & 15 \\
\hline 5 & Rata-rata & 56,80 \\
\hline 6 & Median & 57 \\
\hline 7 & Standar deviasi & 4,72 \\
\hline
\end{tabular}

Secara umum dapat dikatakan bahwa perolehan siswa sebelum perlakuan berupa model pembelajaran berdasarkan masalah masih rendah. Dari 30 orang siswa, hanya 2 orang (7 $\%)$ yang mencapai derajat tuntas.

Apabila skor perolehan siswa dikelompokkan ke dalam lima kategori menurut kategori standar yang ditetapkan Depdikbud, maka diperoleh distribusi frekuensi dan persentase seperti yang terlihat pada tabel 2 . sebagai berikut :
Tabel 2. Distribusi Frekuensi dan Persentase Skor Tes Awal

\begin{tabular}{ccccc}
\hline No & Skor & Kategori & F & $\mathbf{( \% )}$ \\
\hline 1 & $0-34$ & Sangat rendah & 0 & 0 \\
\hline 2 & $35-54$ & Rendah & 7 & 23 \\
\hline 3 & $55-64$ & Sedang & 21 & 70 \\
\hline 4 & $65-84$ & Tinggi & 2 & 7 \\
\hline 5 & $85-100$ & Sangat tinggi & 0 & 0 \\
\hline \multicolumn{6}{c}{ Jumlah } & 30 & 100 \\
\hline
\end{tabular}

Perbandingan antara skor sangat rendah dengan kategori tinggi tidak seimbang, sedangkan perbandingan antara kategori sedang dengan kategori rendah adalah $3: 1$. Hal ini menunjukkan bahwa hasil belajar siswa masih didominasi oleh skor dengan kategori sedang.

Hasil Tes Siklus I

Pasca perlakuan selama satu siklus, skor perolehan siswa mengalami peningkatan meskipun tidak signifikan. Hasil belajar siswa pasca perlakuan siklus 1 dapat dilihat pada tabel berikut:

Tabel 3. Statistik Hasil Belajar Siklus 1

\begin{tabular}{ccc}
\hline NO & STATISTIK & NILAI \\
\hline 1. & Jumlah Siswa & 30 \\
\hline 2. & Nilai tertinggi & 75 \\
\hline 3 & Nilai terendah & 55 \\
\hline 4 & Rentang nilai & 20 \\
\hline 5 & Rata-rata & 64,07 \\
\hline 6 & Median & 62,5 \\
\hline 7 & Standar deviasi & 4,84 \\
\hline
\end{tabular}

Data pada tabel diatas menunjukkan bahwa nilai rata-rata hasil belajar siswa setelah dilakukan model pembelajaran berdasarkan masalah adalah 64,07 dengan standar deviasi 4,84 atau $47 \%$ dari hasil skor ideal (total) yang mungkin dicapai, yaitu 100, sedangkan skor terendah adalah 55 dari skor minimal yang mungkin dicapai yakni 0 (nol). Hal tersebut menunjukkan bahwa secara klasikal hasil belajar tentang aspek-aspek bekerja sama tim yang dicapai pada siklus 1 adalah $47 \%$. Sedangkan secara individu, skor yang dicapai oleh siswa tersebar dari skor minimum 55 sampai dengan skor maksimum 75 atau dalam rentang nilai 20. Hal ini berarti bahwa hasil belajar siswa kelas VI SDN 30 Rumaju Kec. Bajo Kab. Luwu pada siklus 1 didominasi dengan kategori sedang.

Jika skor tersebut diatas dikelompokkan ke dalam 5 (lima) kategori, maka diperoleh 
distribusi frekuensi nilai seperti pada tabel berikut ini.

Tabel 4. Distribusi Frekuensi dan Persentase Skor Tes Siklus 1

\begin{tabular}{ccccc}
\hline No & Skor & Kategori & F & $(\%)$ \\
\hline 1 & $0-34$ & Sangat rendah & 0 & 0 \\
\hline 2 & $35-54$ & Rendah & 0 & 0 \\
\hline 3 & $55-64$ & Sedang & 16 & 53 \\
\hline 4 & $65-84$ & Tinggi & 14 & 47 \\
\hline 5 & $85-100$ & Sangat tinggi & 0 & 0 \\
\hline \multicolumn{6}{c}{ Jumlah } & 30 & 100 \\
\hline
\end{tabular}

Data pada tabel diatas menggambarkan bahwa skor hasil belajar tentang mekanisme kerja sama tim pada siklus 1 terdapat 16 orang (53\%) yang berada pada kategori sedang, 14 orang $(47 \%)$ yang berada pada kategori tinggi. Jika skor rata-rata hasil belajar tentang konsep kerjasama tim 64,07 atau $47 \%$ ( Tabel 1) dikonsultasikan dengan tabel 2 diatas maka skor belajar mereka berada pada interval $55-64$. Hal ini menunjukkan bahwa hasil belajar siswa setelah pelaksanaan Proses Belajar Mengajar (PBM) dengan menerapkan model pembelajaran berdasarkan masalah mencapai kategori sedang.

Meskipun demikian, pengajaran tambahan berupa remedial/pengayaan masih perlu dibeikan sehingga pada akhir suatu proses pembelajaran untuk item tertentu semua siswa dapat mencapai standar ketuntasan belajar seperti diisyaratkan dalam kurikulum. Pembelajaran dikatakan berhasil jika $85 \%$ siswa atau lebih mencapai skor hasil belajar minimal $65 \%$ dari seluruh soal yang diberikan.

3. Hasil Tes Siklus 2

Deskripsi secara kuantitaif hasil belajar siswa berdasarkan tes siklus 2 yakni setelah diadakan perbaikan-perbaikan dan penyempurnaan kegiatan yang dianggap kurang pada siklus 1 dapat dilihat pada tabel berikut ini.

Tabel 5 Statistik Hasil Belajar Siklus 2

\begin{tabular}{ccc}
\hline NO & STATISTIK & NILAI \\
\hline 1. & Jumlah Siswa & 30 \\
\hline 2. & Nilai tertinggi & 85 \\
\hline 3 & Nilai terendah & 65 \\
\hline 4 & Rentang nilai & 20 \\
\hline 5 & Rata-rata & 73,10 \\
\hline 6 & Median & 72 \\
\hline 7 & Standar deviasi & 5,13 \\
\hline
\end{tabular}

Data pada tabel di atas menunjukkan bahwa nilai rata-rata perolehan siswa setelah diadakan tindakan lanjutan adalah 73,10 dengan standar deviasi 5,13 atau $100 \%$ dari skor ideal (total) yang mungkin dicapai yakni 100, sedangkan skor terendah adalah 65 dari skor minimal yang mungkin dicapai yakni 0 . Hal ini menunjukkan bahwa secara klasikal hasil belajar tentang pengendalian penyimpangan sosial yang diperoleh pada siklus 2 adalah $100 \%$. Sedangkan secara individual skor yang dicapai tersebar antara 65 sebagai skor terendah dan 85 sebagai skor tertinggi atau dalam rentang nilai 20. Kenyataan ini menggambarkan bahwa hasil belajar siswa-siswi tersebut termasuk kategori tinggi.

Jika skor perolehan siswa tersebut dikelompokkan ke dalam kategori, maka dipeoleh distribusi frekuensi nilai sebagai berikut:

Tabel 6 Distribusi Frekuensi dan Persentase Skor Tes Siklus 2

\begin{tabular}{ccccc}
\hline No & Skor & Kategori & F & $(\%)$ \\
\hline 1 & $0-34$ & Sangat rendah & 0 & 0 \\
\hline 2 & $35-54$ & Rendah & 0 & 0 \\
\hline 3 & $55-64$ & Sedang & 0 & 0 \\
\hline 4 & $65-84$ & Tinggi & 29 & 97 \\
\hline 5 & $85-100$ & Sangat tinggi & 1 & 3 \\
\hline \multicolumn{6}{c}{ Jumlah } & 30 & 100 \\
\hline
\end{tabular}

Tabel di atas menunjukkan bahwa hasil belajar tentang kerjasama tim pada siklus 2 terdapat 29 orang $(97 \%)$ yang mencapai kategori tinggi dan 1 orang (3\%) yang berada pada kategori sangat tinggi. Skor rata-rata hasil belajar yang dicapai oleh siswa adalah 73,10 yaitu berada pada interval $65-84$. Hal ini berarti bahwa hasil belajar siswa setelah diadakan PBM dengan menerapakan model pembelajaran berdasarkan masalah berada pada kategori tinggi.

Untuk melihat secara langsung signifikansi peningkatan hasil belajar tentang kemampuan pengendalian penyimpangan sosial dari siklus 1 (sebelum perlakuan) sampai siklus 2 (pasca perlakuan) model pembelajaran berdasar dapat dilihat pada tabel berikut ini.

Tabel 7 Statistik Skor Hasil Belajar tentang Bekerja dalam Satu Tim

\begin{tabular}{cccccc}
\hline No & Siklus & Mak. & Min & Mean & Med. \\
\hline 1 & Siklus 1 & 75 & 55 & 64,07 & 62,5 \\
2 & Siklus 2 & 85 & 65 & 73,10 & 72 \\
\hline
\end{tabular}


Dari data pada tabel tersebut diatas dapat dipahami bahwa nilai rata-rata perolehan siswa dari tes siklus 1 sampai ke tes siklus 2 terdapat peningkatan. Hal ini berarti terjadi peningkatan kemampuan siswa dalam menyelesaikan soal-soal yang berhubungan dengan pengendalian penyimpangan sosial setelah melalui model pembelajaran berdasarkan masalah. Informasi lebih lengkap mengenai penigkatan pemahaman dan konsep siswa kelas VI SDN 30 Rumaju Kec. Bajo Kab. Luwu dapat dilihat pada lampiran 1a sampai 1e laporan hasil penilitian ini.

Analisis kualitatif yang akan dibahas pada bagian ini meliputi perubahan sikap mayoritas siswa pasca pemberian bahan ajar melalui pendekatan pembelajaran berdasarkan masalah, refleksi pelaksanaan masing-masing siklus, dan analisis refleksi terhadap tanggapan siswa mengenai pendekatan pembelajaran berdasarkan masalah.

Perubahan Sikap Siswa. Di samping terjadinya kemampuan siswa dalam menyelesaikan soal-soal yang berhubungan dengan kemampuan pengendalian penyimpangan sosial selama proses pembelajaran yakni siklus 1 dan 2, tercatat pula sejumlah perubahan yang terjadi pada sikap siswa. Perubahan tersebut merupakan data kuantitatif yang diperoleh dari kegiatan observasi pada setiap pertemuan yang didapat setiap siklus.

a. Siklus 1

Dalam pelaksanaan tindakan selama siklus 1 berlangsung yakni sebanyak 4 kali pertemuan tercatat sejumlah perubahan sikap pada diri siswa, yaitu:

1) Pada pertemuan awal kehadiran siswa mengikuti kegiatan belajar masih sama seperti sebelum pelaksanaan tindakan, tetapi pada akhir siklus terjadi peningkatan. Hal tersebut ditandai dengan semakin kurangnya siswa yang tidak hadir mengikuti pelajaran seperti terlihat pada lampiran 2 laporan hasil penelitian ini.

2) Keberanian siswa mengajukan pertanyaan dan menanggapi jawaban yang dikemukakan oleh siswa lain semakin meningkat. Demikian pula halnya dengan respon siswa terhadap pertanyaan yang dikemukakan oleh guru.

3) Kemampuan siswa menyelesaikan soal-soal yang dierikan untuk diselesaikan secara individu juga meningkat yang dapat ditandai dengan kurangnya siswa yang terlambat atau tidak mengerjakan tugas.

4) Kemampuan menyelesaikan tugas-tugas kelompok juga tidak pernah lewat dari alokasi waktu yang ditentukan.

b. Siklus 2

Pada siklus 2 tercatat pula sejumlah perubahan penting pada diri siswa yang dapat dirangkum sebagai berikut:

1) Prestasi belajar siswa semakin meningkat yang ditandai dengan semakin banyaknya yang dapat memperoleh skor dengan kategori tinggi. Antusiasme siswa mengerjakan soal-soal yang diberikan juga meningkat meskipun kadangkala satu/dua orang siswa kurang aktif berpartisipasi dalam kegiatan kelompok.

2) Rasa percaya diri siswa juga mengalami peningkatan yang signifikan dengan seringnya memberikan respon tehadap jawaban kelompok lain yang cenderung berbeda dari jawaban anggota kelompok lain maupun kelompoknya sendiri.

3) Semangat kerja sama dan sikap demokratis juga sering ditunjukkan oleh anggota kelompok yang ditandai dengan pemberian kesempatan kepada setiap anggota kelompok untuk mengajukan pertanyaan atau memberikan respon tehadap pertanyaan yang dikemukakan oleh guru maupun oleh anggota kelompok lain.

Refleksi Pelaksanaan Siklus 1.Pada pertemuan 1 sampai 3 , peneliti masih menghadapi berbagai hambatan dalam menyajikan bahan ajar karena kebanyakan siswa belum mampu bekerja sama secara aktif dengan anggota kelompoknya sendiri. Hal itu dimungkinkan karena kelompok dibentuk bukan atas kemauan siswa sendiri melainkan berdasarkan jenis kelamin dan disparitas kemampuan akademik. Imbas dari heterogenitas anggota kelompk itu adalah banyak siswa yang ingin dibimbing langsung oleh guru dibandingkan dengan anggota kelompoknya yang lebih mampu.

Pada pekan kedua, yakni pertemuan tiga dan empat, siswa sudah mampu berinteraksi dengan anggota kelompoknya dalam menghadapi bahan ajar yang disajikan . Bentuk Interaksi tersebut berupa koreksi jika terdapat kesalahan yang dilakukan oleh salah seorang anggota kelompok yang mengerjakan soal di papan tulis. Hanya saja perubahan dimaksud belum mencapai taraf yang diinginkan, yakni 
sikap demokratis yang tidak hanya bersifat kelompok, melainkan juga secra klasikal.

Analisis Refleksi terhadap Tanggapan

Siswa.Pada umumnya siswa menganggap bahwa model pembelajaran berdasarkan masalah jauh lebih baik dari pada pendekatan yang diterapkan sebelumnya. Soal-soal yang tidak dapat diselesaikan secara mandiri dapat diselesaikan melalui kelompok dan dengan waktu yang jauh lebih singkat.

Jika diamati perkembangan prestasi belajar siswa sebelum pemberian bahan ajar dengan menggunakan pendekatan berdasarkan masalah dan pasca perlakuan, diperoleh informasi bahwa ada peningkatan yang cukup signifikan seperti tampak pada lampiran 1a sampai 1d.

Peningkatan tersebut bukan hanya yang bersifat kognitif yang dapat dilihat tetapi juga perubahan sikap diantara siswa terutama yang berhubungan dengan kemampuan menerima keragaman pola dan tingkah laku sesama siswa.

Beberapa orang siswa masih cenderung memilih anggota kelompok yang lebih baik daripadanya. Hal ini menunjukkan bahwa yang bersangkutan belum siap untuk mandiri dan bersaing meskipun dalam konteks kelas. Kondisi seperti ini merupakan imbas penerapan pendekatan berdasarkan masalah yang masih relatif baru bagi mereka..

\section{SIMPULAN DAN SARAN}

Berdasarkan hasil yang diperoleh melalui penelitian tindakan kelas ini maka dapat disimpulkan bahwa :

1. Model Pembelajaran berdasarkan masalah (problem based introduction) dalam pelajaran IPS dapat meningkatkan baik prestasi akademik atau kognitif maupun perubahan sikap (afektif) . Peningkatan kemampuan kognitif dapat dilihat pada peningkatan hasil belajar yang signifikan antara siklus I dengan Siklus II yaitu dari nilai rata-rata 64,07 menjadi 73,10.

2. Secara kualitatif terjadi perubahan sikap siswa dengan melakukan kegiatan-kegiatan positif berupa peningkatan perhatian, motivasi, dan minat siswa terhadap pelajaran IPS terutama pemahaman pengendalian penyimpangan sosial. Sikap demokratis serta kerja sama antara siswa menjadi lebih baik dengan semakin minimnya sekat-sekat kelompok seperti yang ada sebelum pelaksanaan model pembelajaran ini.

Berdasarkan kesimpulan yang diuraikan di atas, maka peneliti menyarankan hal-hal sebagai berikut:

1. Hendaknya setiap guru melakukan penelitian tindakan kelas yang disesuaikan dengan kondisi dan karakteristik siswa serta relevan dengan tuntutan kurikulum.

2. Kepala Sekolah sedapat mungkin mendorong dan memberikan fasilitas kepada setiap guru untuk melakukan penelitian tindakan kelas sesuai dengan tuntutan bahan ajar.

3. Agar setiap sekolah terbentuk Musyawarah Guru Mata Pelajaran sejenis untuk melakukan penelitian tindakan kelas secara kolaboratif. Implementasinya adalah semua guru mata pelajaran bergabung ke dalam satu rumpun menerapkan metode arau model pembelajaran serta teknik yang sama walaupun obyek didik berbeda. Dengan demikian temuan diperoleh lebih valid dibanding jika dilakukan sendiri-sendiri.

\section{DAFTAR RUJUKAN}

Agus,M (2008). Model-Model Pembelajaran SMP.Modul. Makassar: UNM

Makassar.

Arikunto, Suharsimi dkk.(2006). Penelitian Tindakan Kelas. Jakarta :Bumi Aksara.

Furchan, Arief. (1982). Penelitian Dalam Pendidikan.Surabaya :Usaha

Nasional.

Ibrahim, Muslimin dkk. (2000). Pembelajaran Kooperatif. Pusat Sains dan Matematika Sekolah. Surabaya : Program Pascasarjana Unesa.

Mulyasa. (2002). Kurikulum Berbasis Kompetensi.Bandung : :Remaja Rosdakarya.

Nur, Muhammad. (2000). Pengajaran Berpusat kepada Siswa dan Pendekatan Konstruktivis dalam Pengajaran. Surabaya : Pusat Studi Matematika dan IPA Sekolah Universitas Negeri Surabaya.

Peraturan Menteri Pendidikan Nasional RI. Nomor 23 Tahun 2006. Standar 
Kompetensi Lulusan untuk Satuan Pendidikan Dasar dan Menengah. Jakarta : Depdiknas.

Shadily, Hasan. (1991). Ensiklopedia Indonesia. Jakarta : Balai Pustaka.

Sulastri, dkk. (2007). Ringkasan Materi dan Latihan IPS Terpadu.Jakarta : Graha Pustaka.

Tantya. (2008).Ilmu Pengetahuan Sosial Untuk SD/MI Kelas VI.Jakarta : Pusat Perbukuan Depdiknas.

Tim PPG Matematika. (2002). Penelitian Tindakan Kelas. Surabaya : Pusat Studi Matematika dan IPA Sekolah Universitas Negeri Surabaya.

Tim Penyusun Kamus. (1994). Kamus Besar Bahasa Indonesia. Jakarta : Balai Pustaka.

Undang-Undang Republik Indonesia Nomor 20 Tahun 2003 Tentang Sistem Pendidikan Nasional. Jakarta : Departemen Pendidikan Nasional Republik Indonesia 